\title{
THE FACTORS ASSOCIATED WITH ALLERGIC RHINITIS IN THE DYSPHONIC PROFESSIONAL VOICE USERS
}

\author{
Vesna Velickovic ${ }^{1}$,Sladjana Simovic 2 , Sandra Zivanovic ${ }^{3}$, Jasmina Stojanovic 4 , Mladen Koravovic ${ }^{5}$, Natasa Mihailovic ${ }^{6}$ \\ IPediatric Clinic, Clinical Centre Kragujevac, Kragujevac, Serbia \\ ${ }^{2}$ Department of Otorhinolaryngology, Health Centre Kragujevac, Kragujevac, Serbia \\ ${ }^{3}$ Faculty of Hotel Management and Tourism, University of Kragujevac, Kragujevac, Serbia \\ ${ }^{4}$ Phoniatric Department of ENT Clinic, Clinical Centre Kragujevac, Kragujevac, Serbia \\ ${ }^{5}$ Faculty of Pharmacy, University of Belgrade, Belgrade, Serbia \\ ${ }^{6}$ Centre of Informatics and Biostatistics, Institute of Public Health, Kragujevac, Serbia
}

\section{FAKTORI POVEZANI S ALERGIJSKIM RINITISOM KOD DISFONIČNIH PROFESIONALNIH KORISNIKA GLASA}

\author{
Vesna Veličkovićl, Slađana Simović2 ${ }^{2}$ Sandra Živanović3 ${ }^{3}$ Jasmina Stojanovićc, Mladen Koravović5, Nataša Mihailović6 \\ ${ }^{1}$ Klinika za pedijatriju, Klinički centar Kragujevac, Kragujevac \\ ${ }^{2}$ Odeljenje otorinolaringologije, Dom zdravlja Kragujevac, Kragujevac \\ ${ }^{3}$ Fakultet za hotelijerstvo i turizam, Univerzitet u Kragujevcu, Kragujevac \\ ${ }^{4}$ Odsek za fonijatriju, Klinika za otorinolaringologiju, Klinički centar Kragujevac, Kragujevac \\ 5 Farmaceutski fakultet, Univerzitet u Beogradu, Beograd \\ ${ }^{6}$ Centar za informatiku i biostatistiku, Institut za javno zdravlje, Kragujevac
}

\section{ABSTRACT}

Objective. The aim of the present study was to investigate the frequency of allergic rhinitis in dysphonic professional voice users and to assess the correlation between allergic rhinitis and demographic characteristics (sex, ages and years in occupation) and presence of laryngopharyngeal reflux, as comorbidity health condition.

Methods. A total of 104 male and female dysphonic patients who came to the Department of Otorhinolaryngology, Health Centre Kragujevac, Serbia because of the presence of dysphonia symptoms and who used their voice more than 4 hours per day at job were included in the study. The patients underwent rigid or transnasal fiberoptic laryngoscopy with videostroboscopy to assess the causes of dysphonia. Descriptive analysis, Pearson Chi-Square Tests and Binary Logistic regression were carried out using the SPSS 19.0 statistical software package.

Results. Frequency of allergic rhinitis in dysphonic professional voice users was $44.2 \%$. The patients were 1.1 times more likely to have allergic rhinitis with each passing year of life. Allergic rhinitis is with each year in occupation 0.89 times less frequent and 0.035 times less often in patients with laryngopharyngeal reflux.

Conclusion. In dysphonic professional voice users, it has been found that allergic rhinitis occurs rarely with each year in occupation, which means that allergic rhinitis is not a predisposing factor for developing dysphonia, but year in occupation are a protective factor when it comes to the appearance of allergic rhinitis in the examined population.

Key words: rhinitis, allergic; dysphonia; voice.

\section{SAŽETAK}

Cilj. Cilj ovog rada bio je da se analizira učestalost alergijskog rinitisa kod profesionalnih korisnika glasa sa disfonijom, kao i povezanost između alergijskog rinitisa, demografskih karakteristika (pol, starost $i$ dužina radnog staža) i laringofaringealnog refluksa u ispitivanoj populaciji.

Metode. U studiju su uključena ukupno 104 ispitanika muškog $i$ ženskog pola, koji su upućeni u Odeljenje za otorinolaringologiju Doma zdravlja Kragujevac, Srbija, zbog prisustva simptoma disfonije, a zaposleni su na poslovima koji zahtevaju upotrebu glasa više od četiri sata dnevno. Kod ispitanika je primenjena rigidna endovideostroboskopija ili transnazalna fibrooptička laringoskopija da bi se utvrdio uzrok disfonija. Statistička obrada podataka učinjena je primenom deskriptivne metode, Pirsonovog $\chi^{2}$ testa $i$ binarne logističke regresije, korišcenjem standardnog statističkog softverskog paketa SPSS 13.0.

Rezultati. U ispitivanoj populaciji alergijski rinitis, identifikovan je kod 44,2\% profesionalnih korisnika glasa sa disfonijom. U populaciji obuhvaćenoj istraživanjem alergijski rinitis se sa svakom godinom života 1,1 puta češce ispoljava, dok se sa svakom godinom radnog staža 0,89 puta ređe dijagnostikuje. Kod ispitivanih disfoničnih profesionalnih korisnika glasa, kod kojih je ustanovljen laringofaringealni refluks, alergijski rinitis je 0,035 puta ređe prisutan.

Zaključak. Kod disfoničnih profesionalnih korisnika glasa, ustanovljeno je da se alergijski rinitis ređe javlja sa svakom godinom radnog staža, što znači da alergijski rinitis nije predisponirajući faktor za nastanak disfonije, već su godine radnog staža protektivni faktor kada je u pitanju pojava alergijskog rinitisa $u$ ispitivanoj populaciji.

Ključne reči: rinitis, alergijski; disfonija; glas. 


\section{INTRODUCTION}

Dysphonia is an unwanted alteration in human voice, but also a difficulty and/or pain in phonation or speaking. The common causes of organic damages to phonation are acute and chronic inflammatory processes of the larynx and vocal folds mucosa, allergic disease and conditions of the upper and lower respiratory airways or nonspecific chronic laryngitis caused by laryngopharyngeal reflux (LPR). The common functional voice disorders are hyperkinetic dysphonia, psychogenic dysphonia and aphonia, and a special group of dysphonia caused by nodules, polyps, and contact granulomas of the vocal folds (1).

A professional voice user is a person who uses voice in everyday job and therefore the job function critically depends on use of his/her voice. Not only singers and actors, but also teachers, lawyers, clergy, counsellors, telemarketers and many others are among those who use their voices significantly in their line of work (2). In the United States professional voice users make $25-35 \%$ of the working population, and also in other industrialized societies and $1 / 3$ of them have vocal complains $(3,4)$. Vocal folds are susceptible to many predisposing factors such as abusive and excessive vocal behaviour, presence of allergic rhinitis, laryngopharyngeal reflux, lifestyle, general health condition...

Allergic rhinitis (AR) is defined as symptoms of sneezing, nasal pruritus, airflow obstruction, and mostly clear nasal discharge caused by IgE-mediated reactions against inhaled allergens and involving mucosal inflammation driven by type 2 helper T (Th2) cells (5). Allergies as the cause of dysphonia have been discussed in the literature for more than 40 years. Although the existence of laryngeal allergy is controversial, the impact of AR is evident especially for professional voice users. $\mathrm{AR}$ is a common chronic disease and it has been increasing worldwide (5). Although symptoms of AR are rarely severe enough to lead to dysphonia in professional voice users, there is a large body of evidence indicating that AR has a negative impact on the patient's quality of life. In the event of AR, the hypersecretion of the nasal glands causes a postnasal drainage on to oropharyngeal and laryngeal tissue. This leads to the throat clearing, irritating cough, and resultant dysphonia, or a dysphonia as a result of a trouble in nasal breathing and altered resonance characteristics of the upper airway (6).

The LPR has been mentioned in the literature as a predisposing factor for dysphonia, because of the symptoms such as cough, throat clearing, globus pharyngeus, etc. LPR may even lead to carcinoma of the larynx. The LPR is considered to be mainly mediated through a process of exposure of the laryngopharynx to an acid environment in the presence of pepsin (7). The definition of LPR is extraoesophageal variant of gastroesophageal reflux disease, that affects the larynx and pharynx (8).

The objective of this study was to investigate the frequency of AR among dysphonic professional voice users and to assess the correlation between $\mathrm{AR}$ and demographic characteristics (sex, ages and years in occupation) and presence of LPR, as comorbidity health condition, in dysphonic professional voice users.

\section{PATIENTS AND METHODS}

\section{Subjects}

Male and female dysphonic professional voice users (a total of 154) who came to Department of Otorhinolaryngology, Health Centre Kragujevac, Serbia because of the presence of dysphonia symptoms and who use their voice more than 4 hours per day at job, were enrolled in study. A retrospective medical records review was performed of these patients to obtain information about demographic characteristics, living habits, job history and health condition associated with dysphonia such as LPR and AR. AR is diagnosed according to the guidelines of ARIA-Allergic Rhinitis and Its Impact of Asthma group (5). The subjects who had no history of AR were additionally required to exhibit skin prick test. The LPR was diagnosed according to Reflux symptom Index score exceeding 13 and laryngological findings (9).

Dysphonic professional voice users were referred to Phoniatric department of ENT Clinic, Clinical Centre Kragujevac, Serbia, to assess the causes of dysphonias and for treatment. The patients underwent rigid or transnasal laryngoscopy with videostroboscopy, aimed at assessing the exact state of the larynx and determining voice therapy. According to the findings by laryngeal examination, patients with minimal pathologic lesions on vocal folds and functional disorders were included in the study. We excluded patients for whom the anamnesis was positive for smoking habits and women already in postmenopause (50 subjects: 45 for smoking habits, the 6 women were already in postmenopause and one patients had both exclusionary factors). It is well known that smoking habits and hormonal changes in menopause lead to dysphonia.

A total of 104 patients (17 male, 87 female), aged between 18 and 57 years with mean age of 36.8 years ( $\mathrm{SD}=10.9$ years), were included in the study. The mean years in occupation of dysphonic professional voice users were 14.52 years $(\mathrm{SD}=10.72$ years).

The study was conducted in compliance with the Declaration of Helsinki and in accordance with the local Ethical Committee, and all participants gave their written consent to participate in the study. 


\section{Statistical analysis}

All data was entered in a study specific database. Descriptive analysis was used to summarize demographic data. Pearson Chi-Square Tests were used to find associations between the occurrence of AR and sex in professional voice users suffering from dysphonia. A value $\mathrm{p}<0.05$ was considered statistically significant. Binary Logistic regression analyses was carried out to assess the association between AR and sex, ages, years in occupation and presence of LPR expressed as odds ratios (ORs) and 95\% confidence intervals (CIs) between. This analysis was carried out using a repeatedmeasures analysis of an SPSS statistical software package (Statistical Package for the Social Sciences, Version 19.0 for Windows, SPSS, Chicago, IL).

\section{RESULTS}

In the study population the AR was present in $44.2 \%$ patients (46/104). Among dysphonic professional voice users we identified LPR in $14.4 \%$ (15/104). Descriptive characteristics of study sample are reported in Table 1.

Table 1. Descriptive characteristics of study sample

\begin{tabular}{|l|l|l|}
\hline Variable & N & $\%$ \\
\hline Sex & & \\
\hline Male & 17 & 42.5 \\
\hline Female & 87 & 44.2 \\
\hline Age groups & & \\
\hline$\leq 30$ & 34 & 32.7 \\
\hline $31-45$ & 40 & 38.5 \\
\hline$\geq 46$ & 30 & 28.8 \\
\hline Allergic rhinitis & 46 & 44.2 \\
\hline Laryngopharyngeal reflux & 15 & 14.4 \\
\hline Age (mean \pm SD) & $36.80 \pm 10.90$ \\
\hline Year in occupation (mean \pm SD) & $14.52 \pm 10.72$ \\
\hline
\end{tabular}

Due to a considerably smaller number of male subjects $16.3 \%$ (17/104) compared to that of females $85.7 \%$ (87/104), the data of AR presence in the two genders were analyzed separately and among male subjects we found $41.18 \%(7 / 17)$ and among female subjects $44.83 \%$ (39/87). The application of Pearson Chi-Square tests did not reveal a significant association between sex and presence of AR in professional voice users suffering from dysphonia $\left(\chi^{2}=0.625\right.$, df $=1$, $\mathrm{p}=0.429 ; \mathrm{p}>0.05)$.

According to the laryngeal examination the cause of dysphonia among dysphonic professional voice users revealed the presence of glottic insufficiency in 41 patients
Table 2. Otolaryngologic assessment of laryngeal conditions

\begin{tabular}{|l|l|l|}
\hline Variable & $\mathrm{N}$ & $\%$ \\
\hline Glottic insufficiency & 41 & 39.4 \\
\hline Hyperkinetic dysphonia & 23 & 22.1 \\
\hline Vocal nodules & 19 & 18.3 \\
\hline Redness of the vocal fold & 10 & 9.6 \\
\hline Vocal polyps & 4 & 3.8 \\
\hline Reinke's edema & 3 & 2.9 \\
\hline Vocal fold hemorrhage & 3 & 2.9 \\
\hline Cysts & 1 & 0,9 \\
\hline
\end{tabular}

(39.4\%), hyperkinetic dysphonia in 23 (22.1\%), vocal nodules in $19(18.3 \%)$, redness of the vocal folds (acute or chronic laryngitis) in $10(9.6 \%)$, vocal polyps in $4(3.8 \%)$, Reinke's edema in $3(2.9 \%)$, vocal fold hemorrhage in 3 $(2.9 \%)$ and cysts in $1(0.9 \%)$ as presented in Table 2 .

Binary logistic regression has been used by taking into consideration independent variables: sex, age, years in occupation and presence of LPR to dependent variable AR. The model as a whole explained between 18.6\% (Cox \& Snell - R Square) and 24.9\% (Nagelkerke - R Square) variance and accurately classified $64.4 \%$ of the cases. The factors which had an impact on the occurrence of AR were: age, years in occupation and presence of LPR. The most important factor is the age of the patients $[\mathrm{OR}=1.104$ (CI:1.010-1.206)]. With each next year of life, the probability of occurrence of AR is increased by 1.1 times. There was a statistically significant correlation between years in occupation $[\mathrm{OR}=0.889(\mathrm{CI}: 0.809-0.976)]$ and the presence of LPR [OR=0.035 (CI:1.003-0.356) and occurrence of AR, but in a negative direction. The AR is more often found in people who have fewer years in occupation, with each year at work, respondents have 0.89 times less probability of AR occurrence, with all other factors held constant in the model. The AR is 0.035 times less often occurring in patients with LPR. There is no correlation between the occurrence of AR and sex $[\mathrm{OR}=0.447$ (CI:0.129-1.544)]. The results were presented in Table 3.

Table 3. Binary logistic regression

\begin{tabular}{|l|l|l|l|}
\hline Variable & $\mathrm{p}$ & $\operatorname{Exp}(\mathrm{B})$ & $95 \% \mathrm{CI}$ \\
\hline Sex & 0.203 & 0.447 & $0.129-1.544$ \\
\hline Age & 0.029 & 1.104 & $1.010-1.206$ \\
\hline $\begin{array}{l}\text { Years of } \\
\text { occupation }\end{array}$ & 0.014 & 0.889 & $0.809-0.976$ \\
\hline $\begin{array}{l}\text { Laryngopharynge } \\
\text { al reflux }\end{array}$ & 0.005 & 0.035 & $0.003-0.356$ \\
\hline
\end{tabular}




\section{DISCUSSION}

The nasal cavity, like other resonating organs of the supraglottic and subglottic area, attends voice properties: pitch, intensity and timbre $(10,11)$. The AR represents a global health problem with considerable prevalence. Estimates suggest that approximately $10-25 \%$ of the global population and about $23 \%$ of the population in Europe is affected by AR (5). In our study among dysphonic professional voice users we found that AR was present in $42.2 \%$, which is considerably over the known prevalence in the general population. Hamdan AL and colleagues in their study, among singers with nonspecific laryngeal findings used a questionnaire to find out the frequencies of $\mathrm{AR}$ and found it in $93 \%$ of cases (6). Lauriello $\mathrm{M}$ and colleagues analyzed a dysphonic group of 90 patients and found AR in 56.6\% (12) and Brook CD and colleagues reported in $51.9 \%$ patients (13). This leads to the conclusion that this result exceeds the known average which suggests AR as a predisposing factor which may lead to dysphonia. Professional voice users must be able to produce voice in their everyday job. They may lose work because of problems with their voice and may also consider changing career. Dysphonia is for those individuals very frustrating condition and it is caused by multiple factors, with AR being among the important ones. Brook and colleagues examined the allergy test to patients with chronic inflammation of larynx. It was registered that there is a strong correlation between these two (13).

The AR patients with well controlled symptoms basically suffer from constant inflammation. When exposed to aeroallergens or some irritant substance, they can develop more severe symptoms $(14,15)$. Allergy as the only cause of dysphonia was first mentioned in the literature in 1972 . by Williams RI who found that $28 \%$ of his sample patients had it (16).

The AR can be the secondary cause of dysphonia in the presence of LPR. It was found that vasomotor and secretomotor fibers of sympathetic and parasympathetic origin were present in mucosa of the larynx especially in posterior parts and also on vocal folds in the posterior third (17).

There are specific receptors in the mucosa of the larynx sensitive to negative pressure in the nasal cavity and in the rhinopharynx (18). A negative nasal pressure because of AR leads to a reflex increase if the muscular activity of the posterior crico-arytenoid, as recorded by electromyography (19).

Most patients with vocal fold hemorrhage suffer also from LPR, asthma or AR (20). Dysphonia caused by vocal nodules, vocal polyps and Reinke's edema and also functional dysphonia can result from chronic inflammation, aeroallergens, airborne irritants, poor vocal technique, or a mixture of them. Using laryngoscopy, videostroboscopy and/or transnasal fiberoptic examination this study of observed dysphonic professional voice users revealed the presence of glottic insufficiency and hyperkinetic dysphonia, respectively, in $39.4 \%$ and $22.1 \%$ in most cases. The vocal nodules in our study population were $18.3 \%$, redness of the vocal fold in $9.6 \%$, vocal polyps in $3.8 \%$. From the literature data, in the treatment-seeking population for dysphonia, laryngitis or redness of the vocal fold is most frequent laryngeal disease (21). Previous reports have shown the presence of vocal nodules in $16.9 \%$ of teachers and $4.34 \%$ in control group; vocal polyp was revealed in $2.4 \%$ of teachers (22). In the general population study occurrence of vocal nodules was $1.5 \%$ and vocal polyp $0.4 \%$ (23). Reported rates are probably different because of different study population and methodological approach. One previous study which dealt with acoustic analysis of voice, stroboscopic findings of larynx and Voice Handicap Index scores in AR patients compared with control group, also suggests that occurrence of allergies could lead to dysphonia (24).

In this study, no significance was found for frequency of AR between genders. The findings correlate with the data in general population (23). Also, according to the data found by previous studies, voice problems are more frequent in women $(4,12,21)$ because they have shorter vocal folds that produce higher fundamental frequency and because of smaller quantity of vocal folds hyaluronic acid that is essential for wound repair (25). But, these differences can also be due to a higher rate of complaints related to voice in females versus males.

In the observed dysphonic professional voice users, using Binary Logistic regression, we found a statistically significant correlation between years in occupation, presence of LPR and occurrence of AR, but in a negative direction, which means that $\mathrm{AR}$ is frequent in people who have fewer years in occupation, with each year in occupation the respondents have 0.89 times less probability of AR appearance. We must note that the number of years in occupation is not in correlation with age, meaning that the elderly did not have a longer length of service.

The LPR is a frequent finding in voice problems especially among professional voice users whose performances require increased abdominal pressure; because of this they are exposed to develop Gastrooesophageal reflux and LPR. Some authors think that the studies made until now did not confirm that LPR is so much present among dysphonic patients (26-28), and there is a significant overlap in the symptomatic presentation of patients with LPR and allergic laryngitis $(15,28)$. The LPR and AR are difficult to be differentiated because they have similar signs and symptoms as reported. We identified LPR in $14.4 \%$ of the study population and AR is 0.035 
times rarer in patients with LPR. Similar findings were shown in the study of Randhawa PS and colleagues. In their study of dysphonic patients there were three times more patients with allergies than those with LPR. LPR is considered to be one of the common causes of chronic laryngitis, but there are other associated causes as well, as written by Belafsky PC and colleagues utilized an experimental animal model to examine pathogenetic triggers for laryngeal inflammation. The authors concluded that the combination of dust mite antigen and iron soot caused laryngeal eosinophilia with an established guinea pig model of chronic laryngitis thus providing that there were associated predisposing factors that caused dysphonia (30).

\section{CONCLUSION}

Vulnerability of the larynx to various inhaled or ingested allergens is very challenging. Mostly because there is a paucity of clinical and bench research on the subject of allergic laryngitis, there is little consensus in the scientific literature relative to whether or not this condition is a true clinical entity. Our study showed that the AR more often appears in dysphonic professional voice users than in general population. In dysphonic professional voice users, it has been found that AR occurs rarely with each year in occupation, which means that $A R$ is not a predisposing factor for developing dysphonia, but years in occupation are a protective factor when it comes to the appearance of AR in the examined population.

\section{ABBREVIATION}

AR- allergic rhinitis

LPR- laryngopharyngeal reflux

\section{REFERENCES}

1. Djukic V, Stankovic P, Ugrinovic A, DjordjevicV. Dysphonia-dilemmas and controversies. Acta ClinicaHoarseness 2008; 8: 18-20.

2. Sataloff RT. Professional voice users: the evaluation of voice disorders. Occup Med 2001; 16: 633-47.

3. Williams NR. Occupational groups at risk of voice disorders: a review of the literature. Occup Med 2003; 53: 456-60.

4. Bhattacharyya N. The prevalence of voice problems among adults in the United States. Laryngoscope 2014; 124: 2359-62.

5. Bousquet J, Khaltaev N, Cruz AA, et al. Allergic rhinitis and its impact on asthma (ARIA) 2008 update (in collaboration with the World Health Organization, GA(2)LEN and AllerGen). Allergy 2008; 63: 8-160.
6. Hamdan AL, Sibai A, Youssef M, Deeb R, Zaitoun F. The use of a screening questionnaire to determine the incidence of allergic rhinitis in singers with dysphonia. Arch Otolaryngol Head Neck Surg 2006; 132: 547-9.

7. Zalvan $\mathrm{CH}, \mathrm{Hu} \mathrm{S}$, Greenberg B, Geliebter J. A comparison of alkaline water and mediterranean diet vs proton pump onhibition for treatment of laryngopharyngeal reflux. JAMA Otolaryngol Head Neck Surg 2017; 143: 1023-9.

8. Sataloff RT, Hawkshaw MJ, Gupta R. Laryngopharyngeal reflux and voice disorders: an overview on disease mechanisms, treatments, and research advances. Discov Med 2010; 10: 213-24.

9. Belafsky PC, Postma GN, Koufman JA. Validity and reliability of the reflux symptom index (RSI). J Voice 2002; 16: 274-7.

10. Develioglu ON, Paltura C, Koleli H, Kulekci M. The effect of medical treatment on voice quality in allergic rhinitis. Indian J Otolaryngol Head Neck Surg 2013; 65: 426-30.

11. Dworkin-Valenti JP, Sugihara E, Stern N, Naumann I, Bathula S, Amjad E. Laryngeal inflammation. Ann Otol Rhinol 2015; 2: 1058-66.

12. Lauriello M, Angelone AM, Businco LD, Passali D, Bellussi LM, Passali FM. Correlation between female sex and allergy was significant in patients presenting with dysphonia. Acta Otorhinolaryngol Ital 2011; 31: 161-6.

13. Brook CD, Platt MP, Reese S, Noordzij JP. Utility of allergy testing in patients with chronic laryngopharyngeal symptoms: is it allergic laryngitis? Otolaryngol Head Neck Surg 2016; 154: 41-5.

14. Roth DF, Abbott KV, Carroll TL, Ferguson BJ. Evidence for primary laryngeal inhalant allergy: a randomized, double-blinded crossover study. Int Forum Allergy Rhinol 2013; 3: 8-10.

15. Krouse JH. Allergy and laryngeal disorders. Curr Opin Otolaryngol Head Neck Surg 2016; 24: 221-5.

16. Williams RI. Allergic laryngitis. Ann Otol Rhinol Laryngol 1972; 81: 558-65.

17. Wyke BD, Kirschner JA. Neurology of the larynx. London: Heinemann, Scientific Foundations of Otolaryngology, 1976: 546-74.

18. Sant'Ambrogio G, Mathew OP, Fisher JT, Sant'Ambrogio FB. Laryngeal receptors responding to transmural pressure, airflow and local muscle activity. Respir Physiol 1983; 54: 317-30.

19. van Lunteren E, Van de Graaff WB, Parker DM et al. Nasal and laryngeal reflex responses to negative upper airway pressure. J Appl Physiol Respir Environ Exerc Physiol 1984; 56: 746-52. 
20. Stachler RJ, Dworkin-Valenti JP. Allergic laryngitis: unraveling the myths. Curr Opin Otolaryngol Head Neck Surg 2017; 25: 242-6.

21. Cohen SM, Kim J, Roy N, Asche C, Courey M. Prevalence and causes of dysphonia in a large treatment-seeking population. Laryngoscope 2012; 122: 343-8.

22. Preciado-López J, Pérez-Fernández C, CalzadaUriondo M, Preciado-Ruiz P. Epidemiological study of voice disorders among teaching professionals of $\mathrm{La}$ Rioja, Spain. J Voice 2008; 22: 489-508.

23. Hah JH, Sim S, An SY, Sung MW, Choi HG. evaluation of the prevalence of and factors associated with laryngeal diseases among the general population. Laryngoscope 2015; 125: 2536-42.

24. Koç EA, Koç B, Erbek S. Comparison of acoustic and ctroboscopic findings and voice handicap index between allergic rhinitis patients and controls. Balkan Med J 2014; 31: 340-4.

25. Gregory ND, Chandran S, Lurie D, Sataloff RT. Voice disorders in the elderly. J Voice 2012; 26: 254-8.
26. Pendleton H, Ahlner-Elmqvist M, Jannert M, Ohlsson B. Posterior laryngitis: a study of persisting symptoms and health-related quality of life. Eur Arch Otorhinolaryngol 2013; 270: 187-95.

27. Garrett CG, Cohen SM. Otolaryngological perspective on patients with throat symptoms and laryngeal irritation. Curr Gastroenterol Rep 2008; 10: 195-9.

28. Eren E, Arslanoğlu S, Aktaş A et al. Factors confusing the diagnosis of laryngopharyngeal reflux: the role of allergic rhinitis and inter-rater variability of laryngeal findings. Eur Arch Otorhinolaryngol 2014; 271: 743-7.

29. Randhawa PS, Mansuri S, Rubin JS. Is dysphonia due to allergic laryngitis being misdiagnosed as laryngopharyngeal reflux? Logoped Phoniatr Vocol 2010; 35: 1-5.

30. Belafsky PC, Peake J, Smiley-Jewell SM, Verma SP, Dworkin-Valenti J, Pinkerton KE. Soot and house dust mite allergen cause eosinophilic laryngitis in an animal model. Laryngoscope 2016; 126: 108-12. 